\title{
The Influence of Personality Characteristics on Teachers and Students in Architectural Design Studio Projects in Some Selected Nigerian Universities
}

Peter Adewuyi, Aderonmu

Covenant University, Nigeria; peter.aderonmu@covenantuniversity.edu.ng

Dare Ojo, Omonijo

Covenant University, Nigeria; omonijoojo@yahoo.com

Michael Chibuzor, Anyaegbunam

Nnamdi Azikiwe University, Nigeria

Samuel Adebayo Amole

Obafemi Awolowo University, Nigeria

Doi:10.5901/mjss.2016.v7n2s1p20

\begin{abstract}
This study reviewed and analyzed the extroversion-introversion characteristics of teachers and students as well as the implications of interface issues on architectural design studio outcomes. The study engaged a structured questionnaire to collect information from a sample of 546 respondents (both students and staff-teachers/mentors). The study found a difference in design approach of students who preferred acting first before thinking and reflection across selected schools of architecture. It also found a difference in the design outcomes of students who are usually open and motivated by outside world in the selected schools. Moreover, the study discovered a difference in design approach of students who enjoy wide variety and changing relationship in the selected schools. It recommended that the synergy of polar characteristic differences of the students be better engaged by the design 32 studio teachers during training in school to prepare for professional competency in practice.
\end{abstract}

Keywords: Architecture, characteristics, extraversion-introversion, influence, teachers, students

\section{Introduction}

Personality characteristic is defined as a particular way in which individual thinks, feels, and behaves; embraces a person's moods, attitudes and opinions, most clearly expressed in interaction with other people.

Several articles have featured prominently on the influence of personality types on students and teachers in developed societies (Lawrence, 1984; Schmeck, 1985; Demirbas, 2001; Demirbas, and Demirkan, 2003; Casakin, 2005; Casakin, 2006; Groulx, 2010). In respect of personality types and architectural discourse, Kvan and Yunyan (2005) found a significant correlation between learning styles and academic performance. Also, Dermibas and Dermikan (2003) examined the implications of learning style preferences on student performance during the design process and found statistically significant differences between the performance scores of students with diverse learning styles at different stages of the design process. These investigators according to Casakin and Miller, (2008) also indicate that the scores of students with different learning styles increased at the end of the design process.

In sub-Saharan Africa (SSA), the influence of extraversion and introversion personalities on academic performances of students, most importantly, has received little attention in literature. Though, a few studies have emerged on the influence of personality type on students development (Rotimi, Omonijo and Uche, 2014; George, Anyaegbunam, Azuh, Chine and Omonijo 2015). However, it could be observed that examining the personality characteristics of students and teachers in relation to Architectural design studio has been relatively ignored in literature in Nigerian context. It is on this note that this study was conceived. The study intends to find out if: (i) there is a difference in design approach of students who preferred acting first before thinking and reflection across selected schools of 
architecture, (ii) there is a difference in the design outcomes of students who are usually open and motivated by outside world in the selected schools, (iii) there is a difference in design approach of students who enjoy wide variety and changing relationship in the selected schools.

The importance of this study hinges on the fact that attitudes and behaviour of students at every stage of architectural design could determine the outcome of the final stage of the design and the success of students' concerned in their projects. The study proceed in the following order: introduction, literature review, methodology, findings and recommendations

\section{Literature Review}

The personality study had its origins in the fundamental idea that people are distinguished by their characteristic individual patterns of behavior; the distinctive ways, in which they walk, talk, furnish their living quarters or express their urges (TNEB, 2007). In the absence of unstructured pedagogy and inability of the architectural teachers and students to engage personality characteristics optimally; there would be gross inadequacies in the service rendition especially in the training of the future professionals who will be directly connected with varying categories of client-users and other beneficiaries of services. In this scenario, both the trainers and trainees have unique personality characteristics which need to be in coherence with one another in order to produce tangible results. Characteristics of this nature are described as indices such as: Extraversion-Introversion, sensing and intuition, thinking and feeling, and perception and judgment.

\subsection{Extraversion-Introversion Index}

Divergent views of personality traits pervade literature. Based on the work of Jung, (1971), in his theory of psychological types, human beings are characterized as follows;

- Extraverted (E) vs. Introverted (I), which deals with the preference of general attitude.

- Sensing (S) vs. Intuition (N), which deals with the preference of one of the two functions of perception:

- Thinking $(T)$ vs. Feeling $(F)$, which deals with people's preference of one of the two functions of judging:

However, Jung, (1971) ideas, presented above are dichotomies, which means each of the above poles represents a different preference. Also, Jung, (1971) argues further that one of the above four functions is dominant - either a function of perception or a function of judging. However, Briggs, (1980) a scholar who subscribed to Jung's (1971) theory, put forward judging-perceiving relationship in the following fourth dichotomies, with a strong belief that they influence personality type (Briggs, 1980)

a. Extraversion - Introversion, means outer expression of mankind, while introvert persons have internal expression.

b. Sensing - Intuition, this is the method by which an individual perceives information. Sensing indicates that an individual mainly believes information he or she receives directly from the external world. Intuition means that a person believes mainly information he or she receives from the internal or imaginative world.

c. Thinking - Feeling, indicates how an individual processes information. Thinking means that a person makes a decision mainly through logic. Feeling means that, as a rule, he or she makes a decision based on emotion (based on what they feel they should do).

d. Judging - Perceiving, meaning how an individual uses the information he or she has processed. Judging means that a person organizes all of his life events and, as a rule, sticks to his plans. Perceiving means that he or she is inclined to improvise and explore alternative options.

In the context of this paper, extraversion-introversion index indicates how students and staff deal with characters they encounter in the process of architectural designing.

\subsection{Students Orientation to Life: Extravert (e) versus Introvert (i)}

In describing orientation to life in terms of architectural design studio, both students and Teachers have two faces where they experience learning and teaching in the same way or differently. These faces are:

- The outer world of activities of mankind.

- The inner world of thoughts, ideas and imaginative activities of people.

Every person has two faces. One face is directed towards the outer world of activities, excitements, people and things. The other face is directed towards the inner world of thoughts, interests, ideas and imaginations. Based on this, 
therefore, this aspect of study shall be in the following three sections.

Firstly, the personality characteristics of both students and teachers, which involves orientation of peoples life, extravert, introvert and perception (sensing versus intuitive).

Secondly, the relationship in the personality characteristics between teachers and students.

Thirdly, the summary of these relationships with particular reference to its pedagogic implication on design studio teaching and learning.

For the purpose of investigation, this study focussed on one aspect of the personality characteristics' spectrum of the architect-designers- The Extrovert and Introvert. The exploration navigates its exploration in the direction of how the trainers and the trainees exhibit these characteristics in the architectural design activities. This descriptive analysis showed the preferences of these actors (participations) in rendering services to client-users of a building project.

\section{Methods}

\subsection{Study Design}

This study employed a survey research designs.

\subsection{Population of Study and Sample Size}

Both students and the members of staff constituted the population of this study. Students were 500 while their teachers were 75 in number, resulting in 575 . Out of these figures, a sample of 546 (Ns=497; Nt=49) was drawn. Ns represent a sample of 497 students while $\mathrm{Nt}$ represented a sample of 49 members of the teaching population.

\subsection{The Design Studio in Universities Under Study.}

This section presents architectural design studio and the description of each of the four universities under study as indicated below:

\subsubsection{Covenant University (CU), School of Architecture, Ota}

The department of architecture, CU, was established in 2002 (Covenant University, 2013). The design studios of the department are located on the top most floors of the College of Science and Technology. It is operated under the auspices of College of Science and Technology with other courses like Estate Management and Building Technology. The department is in conformity with the two-tier system recommendation of accreditation- four (4) years B.Sc. and two years M.Sc. degrees (CU, 2013).

\subsubsection{Ladoke Akintola University of Technology (LAUTECH), School of Architecture, Ogbomoso.}

The department of architecture, LAUTECH, is located within the School of Environmental Sciences; with other courses like Urban and Regional Planning, Fine and Applied Arts, Estate Management and Building (Architecture Departmental Handbook, LAUTECH 2013). Based on the information retrieved from the above mentioned handbook, the school occupies its own building (bungalow) with five studios for B.Tech and two studios for M.Tech degrees. The staff offices and other administrative offices are located within this building.

\subsubsection{Obafemi Awolowo University (OAU), Ile-Ife, Osun State}

OAU, lle-Ife, established Architectural Department as a distinct academic unit in 1982 when the faculty of environmental design and management was created (OAU, 2012). It is situated on a hilly side and geometrically constructed with a taste of creativity. It consists of four (4) interlocking studios for B.Arch. and two (2) studios for M. Arch. adjoined to these studios are staff offices OAU, (2012) which are circumferentially located to suit the purpose and mode of operations of studio pedagogy i.e to make communication and teaching easier with the students in their studios. 


\subsubsection{University of Lagos (UNILAG)}

Professor J.S Myers of the school of architecture, Minnesota started the school of architecture university of Lagos as one of the university projects (UNILAG, 2012). Academic programme commenced in 1971/1972 with the enrolment of eighteen (18) students for the B.Es programme. The first product of the masters' degree programme graduated in 1975/1976.

The school later metamorphosed the programme leading to the award of B.Es, B. Arch professional degree in architecture. Today, B.Es and M.Es degrees are awarded in conformity with the NIA/ARCON accreditation standards. Other programmes are run in parallel like the postgraduate Diploma executive and M.Es programmes (UNILAG, 2012).

\subsection{Research Techniques}

Multistage research technique was applied to select respondents from the population. The population was divided into four universities.

\subsection{Research Instrument}

Structured questionnaire was used to collect information from the sample (Ns=497; $N t=49$ ), where $N s$ is number of respondent students and $\mathrm{Nt}$ is number of respondent Teachers. The questionnaire reflected the personality characteristics of architecture students as designed by the Myers-Briggs Type Indicator (MBTI; AAP, 1997-2009) (Myers, 1980). The Myers-Briggs personality assessment tool is based on four different measures, with each pole designated by descriptive word and a corresponding letter indicated below:
i. Orientation to life: Extravert (E) versus Introvert (I)
ii. Perception: Sensing (S) versus Intuitive (N)
iii. Decision-making: Thinking $(T)$ versus Feeling $(F)$
iv. Attitude to outside world: Perceptive (P) versus Judgmental (J) (Myers, 1980).

\subsection{Limitation of study}

The generic outcome of indices in this study did not directly and individually measure the comparism of the participants responses weighed over the design content, form and expressions.

\subsection{Analysis of Objectives}

\subsubsection{Respondents as Students who 'Preferred acting first before Thinking and Reflection'}

Out of $525(100 \%)$ respondents, about $492(93.7 \%)$ declared their way of orientation to issues in architectural design studio. The rest $33(6.3 \%)$ account for the missing values.

The results in Table 1 shows that the majority 252(51.2\%) respondents as students like to act first before thinking and reflection over architectural design studio issues while only less than half 105 (21.4\%). This suggests that for these particular samples of respondents in the selected schools, it simply means that respondents that like acting first before thinking and reflection were almost double in numbers than those that think and reflect first before acting.

Table 1: Cross Tabulation for Respondents as Students and Teachers 'who Like acting first before thinking and reflection'

\begin{tabular}{|c|c|c|c|c|c|c|c|c|}
\hline \multirow[t]{3}{*}{ University } & \multicolumn{8}{|c|}{ Like acting first before thinking and reflection } \\
\hline & \multicolumn{4}{|c|}{ Respondents as Students } & \multicolumn{4}{|c|}{ Respondents as Teachers } \\
\hline & not like me & very little like me & like me & a lot like me & not like me & very little like me & like me & a lot like me \\
\hline UNILAG & $14(12.6)$ & $4(3.6)$ & $36(32.4)$ & $20(18.0)$ & $12(66.7)$ & $3(16.7)$ & 2(11.1) & $1(5.6)$ \\
\hline O.A.U & 17(13.8) & 18(14.6) & $43(35.0)$ & 14(11.4) & $7(70.0)$ & $2(20.0)$ & $0(.0)$ & $0(.0)$ \\
\hline & $1(.8)$ & $8(6.2)$ & $56(43.4)$ & $24(18.6)$ & $4(44.4)$ & $2(22.2)$ & $2(22.2)$ & 1(11.1) \\
\hline LAUTECH & 19(14.7) & $24(18.6)$ & $42(32.6)$ & $17(13.2)$ & $5(41.7)$ & $1(8.3)$ & $3(25.0)$ & $0(.0)$ \\
\hline \multirow[t]{2}{*}{ Total } & $51(10.4)$ & $54(11.0)$ & $177(36.0)$ & $75(15.2)$ & 28(57.1) & $8(16.3)$ & $7(14.3)$ & $2(4.1)$ \\
\hline & \multicolumn{2}{|c|}{$\begin{array}{l}\text { Introverted Personality } \\
\text { Characteristics=105(21.4) }\end{array}$} & \multicolumn{2}{|c|}{$\begin{array}{l}\text { Extraverted Personality } \\
\text { Characteristics }=252(51.2)\end{array}$} & \multicolumn{2}{|c|}{$\begin{array}{l}\text { Introverted Personality } \\
\text { Characteristics }=36(73.4)\end{array}$} & \multicolumn{2}{|c|}{$\begin{array}{c}\text { Extraverted Personality } \\
\text { Characteristics= } \\
9(22.5)\end{array}$} \\
\hline
\end{tabular}

Figure in Bracket Presents Percentages, Number outside the Bracket represents Frequencies 
In other words, considering the statistics, the scores: mean (3.3476), median (4) and mode (4.0) supported these assertions. This could be a direction on the pedagogical gap created as a result of (i) less awareness of the learners to place cognizance on their personal characteristics (ii) inappropriate application of personal characteristics (iii) teachers style of handling brief and project assignments, etc. of which may indirectly or directly affect the performance expectation in architectural design studio work.

\subsubsection{Implication for Teaching}

The architectural design studio pedagogic process requires thinking and reflection first before acting on a particular design idea. From the selected respondent samples, the findings indicated that a majority of the 252 respondents like acting first (extraverted $=51.2 \%$ ) before thinking and reflection while less respondents 105 (introverted $=21.4 \%$ ) did not; out of the 492 respondents, the rest accounts for the respondents with indecision. The implication for teaching calls for teachers to strategize their instructional strategies to cater for learners in the other category. It is generic at initial stage of architectural design studio process, thinking and reflection precedes acting on any particular issue. Therefore, the pedagogical predilection could incorporate design exercises that involve design thinking at initial stage. Although, this may favour respondents who like to think and reflect first before acting. At problem identification and definition stage, this result suggests that both thinking and reflecting are relevant to properly establish objective goal in any experiential project. Architectural education as a learning-by-doing practice, also involve acting (or action), so, in between initiation stage of design process and action stage, there is a great need at some critical points to act on some design decisions.

The strongest personality characteristics was 'Like acting first before reflection and thinking' which was identified with extraverted characteristics with the highest mean value of 3.3476 and mean attributed scores of 329.4 (TAS=1647) while the least introverted characteristics of mean attributed cores 294 (TAS=1470, tables 7.1.4 and 7.1.8) was preference for outer world of activities. The mean scores across the selected schools for the 5-tested personality characteristics were: $3.3476,3.1408,2.7947,2.8529$, and 2.9697 respectively.

These inferences are simply attributed to the (i) thinking ability of architect (ii) reflection ability (iii) acting or active Orientation.

Table 2: Personality Characteristics and Measures of Central Tendency

\begin{tabular}{|l|c|c|c|c|c|}
\hline \multicolumn{1}{|c|}{$\begin{array}{c}\text { Measures of Central } \\
\text { Tendency }\end{array}$} & $\begin{array}{c}\text { Like acting first } \\
\text { before thinking } \\
\text { and Reflection }\end{array}$ & $\begin{array}{c}\text { Feel deprived } \\
\text { when cut off from } \\
\text { interaction }\end{array}$ & $\begin{array}{c}\text { Usually Open and } \\
\text { Motivated by } \\
\text { outside world }\end{array}$ & $\begin{array}{c}\text { Enjoy wide variety } \\
\text { and Changing } \\
\text { Relationship }\end{array}$ & $\begin{array}{c}\text { Outer World of } \\
\text { Activities to One-to- } \\
\text { One Communications }\end{array}$ \\
\hline Frequency & 492 & 497 & 492 & 476 & 495 \\
Mean & 3.3476 & 3.1408 & 2.7947 & 2.8529 & 2.9697 \\
Median & 4.000 & 3.0000 & 3.0000 & 3.0000 & 3.0000 \\
Mode & 4.00 & 4.00 & 3.00 & 3.00 & 2.00 \\
Sum Attributed Scores(TAS) & 1647.00 & 1561.00 & 1375.00 & 1358.00 & 1470.00 \\
\hline Mean Attributed Scores & 329.4 & 312.2 & $\mathbf{2 7 5}$ & $\mathbf{2 7 1 . 6}$ & $\mathbf{2 9 4}$ \\
\hline
\end{tabular}

From Table 3, out of $100 \%$ valid responses, 33\% indicated like me, $10.5 \%$ a lot like me(sum of $43.5 \%$ ), and $10.3 \%$ not like me and $19.3 \%$ very little like me(sum of $29.6 \%$ ).

Therefore, the ratio of the respondents that feel deprived when cut off from interaction to the one who do not is 43.5: 29.6(1.5:1 approx.). Generally in these selected schools, it suggests that those that regularly require an amount of 'private time' to recharge batteries were less by $29.6 \%$ (introverted), those who like interaction with outside world were more by $43.5 \%$ (extraverted), while $22 \%$ were of neutral opinion. The scores mean (3.14), median (3.00) and mode (4.00) supported these findings.

Table 3: Cross Tabulation for Respondents as Students who 'Feel deprived when cut off from interraction'

\begin{tabular}{|l|c|c|c|c|c|c|}
\hline \multirow{2}{*}{ University } & \multicolumn{5}{|c|}{ Feel deprived when cut off from interaction } & \multirow{2}{*}{ Total } \\
\cline { 2 - 6 } & not like me & very little like me & a little like me & like me & a lot like me & \\
\hline UNILAG & $1(.9)$ & $19(16.7)$ & $42(36.8)$ & $42(36.8)$ & $10(8.8)$ & $114(100.0)$ \\
O.A.U & $20(16.0)$ & $35(28.0)$ & $18(14.4)$ & $40(32.0)$ & $12(9.6)$ & $125(100.0)$ \\
CU & $10(7.8)$ & $15(11.6)$ & $39(30.2)$ & $44(34.1)$ & $21(16.3)$ & $129(100.0)$ \\
LAUTECH & $20(15.5)$ & $27(20.9)$ & $35(27.1)$ & $38(29.5)$ & $9(7.0)$ & $129(100.0)$ \\
Total & $\mathbf{5 1 ( 1 0 . 3 )}$ & $\mathbf{9 6}(19.3)$ & $\mathbf{1 3 4}(27.0)$ & $\mathbf{1 6 4 ( 3 3 . 0 )}$ & $\mathbf{5 2 ( 1 0 . 5 )}$ & $\mathbf{4 9 7 ( 1 0 0 . 0 )}$ \\
\hline
\end{tabular}

\begin{tabular}{|l|l|l|}
\hline Introverted Personality Characteristics=147(29.6) & Undecided (27.0) & Extraverted Personality Characteristics=216(43.5) \\
\hline
\end{tabular} 
Therefore, the personal characteristics in these samples emphasized more innate preference for drawing synergy from outward energy (orientation). This suggest possibly boredom experience from long hours of sitting down, late nights keeping and other associated sub-components impart of design studio culture. This could also indicate a pedagogic direction why some design studios are deserted without prompt attendance to its restoration.

By these enquiries and resulted findings, the pedagogues (teachers) and other stakeholders need to innovate the design studio culture by revisiting the policies and curriculum context relevance. The architectural design studio can be made an interesting experience to the users, thereby recreating studio to the conduciveness of learners.

\subsubsection{Lump Frequency Chart for Students 'Who are usually open and motivated by Outside World'}

From Table 4 below, 30.7\% respondents were usually open and motivated by outside world, while $40.1 \%$ are usually motivated internally, in order words, their mind is closed to outside world. The latter category solely depends on their intuitions, imaginations; expressions and rose-coloured fantasies. This indicates that generally across the four selected schools, more respondents had in their personality characteristics, the abilities to work within the dictates of their minds not minding the world around them. But on the individual school basis, this result shows various affinity degrees of the respondents in each school of the personality characteristics to be or to not be usually open and motivated by outside world.

Table 4: Lump Frequency Chart for Respondents Students 'Who are usually open and motivated by Outside World'

\begin{tabular}{|l|c|c|c|}
\hline Degree of Preference & Frequency(per cent) & Extraverted Characteristics(per cent) & Introverted Characteristics (per cent) \\
\hline not like me & $89(18.1)$ & & \\
very little like me & $108(22.0)$ & & \\
a little like me & $144(29.3)$ & 30.7 & \\
like me & $117(23.8)$ & & \\
a lot like me & $34(6.9)$ & & \\
\hline \multicolumn{1}{|c|}{ Total } & 492(100.0) & & \\
\hline
\end{tabular}

Figure in Bracket Presents Percentages, Number outside the Bracket represents Frequencies

In Table 5, across the whole selected schools, more 197(40.1\%) respondents as students had domineering instincts of introverted personality characteristics, O.A.U with the strongest likelihoods of 23(18.4\%), 47(37.6\%) respectively. While less respondents 151(30.7\%) with extraverted personality characteristics of "being usually open and motivated by Outside World' was recorded in LAUTECH School of architecture with its strongest likelihoods of $48(37.5 \%), 11(8.6 \%)$ respectively.

Table 5: Cross Tabulation of Respondent Students 'Who are usually open and motivated by Outside World'

\begin{tabular}{|l|c|c|c|c|c|c|}
\hline \multirow{2}{*}{ University } & \multicolumn{3}{|c|}{ Usually Open and Motivated by outside world people and things } & \multirow{2}{*}{ Total } \\
\cline { 2 - 6 } & not like me & very little like me & a little like me & like me & a lot like me & \\
\hline UNILAG & $38(34.2)$ & $23(20.7)$ & $22(19.8)$ & $22(19.8)$ & $6(5.4)$ & $111(100.0)$ \\
O.A.U & $23(18.4)$ & $47(37.6)$ & $24(19.2)$ & $25(20.0)$ & $6(4.8)$ & $125(100.0)$ \\
CU & $21(16.4)$ & $11(8.6)$ & $63(49.2)$ & $22(17.2)$ & $11(8.6)$ & $128(100.0)$ \\
LAUTECH & $7(5.5)$ & $27(21.1)$ & $35(27.3)$ & $48(37.5)$ & $11(8.6)$ & $128(100.0)$ \\
Total & $89(18.1)$ & $108(22.0)$ & $144(29.3)$ & $117(23.8)$ & $34(6.9)$ & $492(100.0)$ \\
\hline
\end{tabular}

\begin{tabular}{|l|l|l|}
\hline Introverted Personality Characteristics=197(40.1) & Undecided & Extraverted Personality Characteristics=151(30.7) \\
\hline
\end{tabular}

Figure in Bracket Presents Percentages, Number outside the Bracket represents Frequencies

\subsubsection{Implication for Pedagogical Instruction and Mentoring}

Pedagogical instruction and mentoring requires that teachers should develop different ways of delivering balance teaching for different categories of students. In this particular design studio set up, there would be emergent needs to reorganize the design studio setting, programming of activities and curriculum development. In a situation where there were more who are usually motivated internally, hidden curriculum aspects like field trips, workshops, brainstorming and group works can be instituted within the studio programmes.

Teachers should strive to provide a variety of learning experiences, such that at one point or another each learning 
style is addressed along with the personality characteristics. When more introverted respondent characteristic was 40.1 $\%$ of 'not being usually opened and motivated by outside world'; it is a pointer that the architectural design studio teachers and stakeholders needs to restructure their instructional guides and tools (instructional shift). Studio teachers may need to incorporate certain instructional diets, guidelines and strategies which will stimulate response from this category of respondents in order to be inspired by the outside world.

Table 6: Cross Tabulation for Respondent Students who 'Enjoy wide variety and Changing Relationship'

\begin{tabular}{|c|c|c|c|c|c|c|}
\hline \multirow[t]{2}{*}{ University } & \multicolumn{6}{|c|}{ Enjoy wide variety and Changing Relationship } \\
\hline & not like me & very little like me & a little like me & like me & a lot like me & Total \\
\hline UNILAG & $15(14.7)$ & $17(16.7)$ & $38(37.3)$ & $20(19.6)$ & $12(11.8)$ & $102(100.0)$ \\
\hline O.A.U & $16(13.3)$ & $37(30.8)$ & $35(29.2)$ & $20(16.7)$ & $12(10.0)$ & $120(100.0)$ \\
\hline $\mathrm{CU}$ & $19(14.8)$ & $10(7.8)$ & $34(26.6)$ & $44(34.4)$ & $21(16.4)$ & $128(100.0)$ \\
\hline LAUTECH & $39(31.0)$ & $45(35.7)$ & $14(11.1)$ & $22(17.5)$ & $6(4.8)$ & $126(100.0)$ \\
\hline Total & $89(18.7)$ & $109(22.9)$ & $121(25.4)$ & $106(22.3)$ & $51(10.7)$ & $476(100.0)$ \\
\hline
\end{tabular}

Figure in Bracket Presents Percentages, Number outside the Bracket represents Frequencies

The results will help to ginger creativities in their design works and prevent boredom and desertedness from studio. Such instructional shift and methods will help to tap inspiration from outside world. All Stakeholders alike need to look into the issues on curriculum innovation, reformation and sustainability. In this same vein, certain vocational subjects (VTE) and courses may need to be introduced to diet the curriculum and programme.

In another sense, the systematic-design process needs to be revisited from initiation to action stage of design project development, feedback process and assessment methods. In this case, students' design will no longer be dominated by their own thoughts, imaginations, and unworkable fantasies. For Teachers are obliged to mould their thoughts by supervision, mentoring, crits and assessments.

It indicates that only few 'enjoyed wide variety and changing relationship'. This could be attributed to the camaraderie habitués of design studio culture. The occurrence may be as a result of having constant relationship with only architecture students, seeing the same set of people with the same genres, language, attitudes and struggle patterns and colour every day.

\subsubsection{Pedagogical Implication and Paradigm Shift}

Architectural design studio teachers need to re-organize design studio setting in a way to make the students interact with other students by having inter schoolffaculty exchange programmes with other students with various orientation, perception, pedagogic inclination, predilections, socio-cultural backgrounds, and learning environments.

In this result, there was a strong predilection for most respondents 198(41.6\%) who reject wide variety and Changing Relationship among peers in architecture schools and outside the school. The unpleasant experiences here could result to anti-social, rigid, bad temperament, low self esteem, loss of interest and deviant behaviors all against career pursuit, and future aspiration. Such students would find it difficult to relate with peers while in schools and more difficult to rapport with clients if they eventually graduates from school of architecture.

The architectural design studio teaching, crits, jury and studio instructional process requires that teachers should relate to students by one-to-one communication. The teachers move from one table to another checking each stage of design project. Although, there are stages in which lectures and seminars are given in order to prepare students for the design studio activities. This could be done at the beginning of a design project to allow students understand the purpose (aim, objectives and target goal) of the assigned project.

In the above statistics, the respondents indicated $36.8 \%$ preference for one-to-one communication with while $38.4 \%$ signified preference for outer world of activities. The preferences were almost equal in percentage, with extraverted (36.8\%) and introverted (38.4\%) respectively. 
Table 7: Frequency Chart for Students who 'prefer outer World of Activities to One-to-One Communications'

\begin{tabular}{|l|c|c|c|c|c|c|}
\hline & \multicolumn{3}{|c|}{ Prefer outer World of Activities to One-to-One Communications } & \multirow{2}{*}{ Total } \\
\cline { 1 - 5 } University & not like me & very little like me & a little like me & like me & a lot like me & \\
\hline UNILAG & $13(11.4)$ & $19(16.7)$ & $28(24.6)$ & $34(29.8)$ & $20(17.5)$ & $114(100.0)$ \\
O.A.U & $11(8.9)$ & $24(19.4)$ & $42(33.9)$ & $39(31.5)$ & $8(6.5)$ & $124(100.0)$ \\
CU & $12(9.4)$ & $39(30.5)$ & $34(26.6)$ & $37(28.9)$ & $6(4.7)$ & $128(100.0)$ \\
LAUTECH & $19(14.7)$ & $53(41.1)$ & $19(14.7)$ & $24(18.6)$ & $14(10.9)$ & $129(100.0)$ \\
Total & $\mathbf{5 5 ( 1 1 . 1 )}$ & $\mathbf{1 3 5 ( 2 7 . 3 )}$ & $\mathbf{1 2 3 ( 2 4 . 8 )}$ & $\mathbf{1 3 4 ( 2 7 . 1 )}$ & $\mathbf{4 8}(9.7)$ & $\mathbf{4 9 5 ( 1 0 0 . 0 )}$ \\
\hline
\end{tabular}

\begin{tabular}{|l|l|l|l|}
\hline Introverted Personality Characteristics $=190(38.4)$ & Undecided & Extraverted Personality Characteristics $=182(36.8)$ \\
\hline
\end{tabular}

Figure in Bracket Presents Percentages, Number outside the Bracket represents Frequencies

\subsubsection{Implication for Teaching and Learning}

The respondents that liked outer world of activities as weighed over those that prefer one-to-one communication; the ratio is 36.8: 38.4. It suggests that those that preferred on-to-one communication as required in architectural design studio were a little bit more in numbers than those that preferred outer world of activities. The implication for teaching is simply competitive. It requires that the architectural design studio teachers, instructors and mentors needs to take care of the close demands on both sides.

By re-organizing their studio settings, styles of teaching and other motivational strategies, therefore, further enquiries needs to be made on how design studio can be made more interesting by spicing the studio teaching techniques employed in one-to-one communication with pedagogic diets of world of activities. This could mean that oneto-one communication can be mixed with motivational stories, group discussion, field trips, and demonstrations by means of visual aids.

While respondents that prefer outer world of activities can be assisted to enjoy one-to-one communication by involving them in personal projects that will engage them in having personal contacts with supervisors and mentors regularly. To achieve this, such group of students can deliberately strategized into working groups involved in field trips, construction site works and public lectures.

\subsection{Respondents as Students 'who feel Deprived when cut off from Interaction with the Outside World'}

From Table 8, the lump sum (total) of extraverted characteristics is $43.5 \%$ of those who feel deprived when cut off from Interaction with the outside World. But the personality characteristic was stronger in Covenant University 65(50.4) and less in Ladoke Akintola University of Technology schools of architecture, LAUTECH 47(36.5). For introverted characteristics, the lump sum (total) is $29.6 \%$ (Table 8). The personality traits or a characteristic in this regard was stronger in O.A.U, lle-Ife 55(44) with $11.0 \%$ out of the total respondents (29.6\%) respondents' characteristics. It was least in University of Lagos 20(17.6).

Table 8: Frequency Tabulation across Four (4) Selected Schools for Respondents as Students 'Who feel Deprived when cut off from Interaction with the outside World'

\begin{tabular}{|l|c|c|}
\hline University & Frequency (per cent) for Extraverted Characteristics & Frequency(per cent) For Introverted Characteristics \\
\hline UNILAG & $52(45.6)$ & $20(17.6)$ \\
O.A.U & $52(41.6)$ & $55(44)$ \\
CU & $65(50.4)$ & $25(19.4)$ \\
LAUTECH & $47(36.5)$ & $47(36.4)$ \\
Total & $216(43.5)$ & $147(29.6)$ \\
\hline
\end{tabular}

Figure in Bracket Presents Percentages, Number outside the Bracket represents Frequencies

Chi-Square Tests: Pearson Chi-Square:46.570(a) values; $d f=12$; Asymp.Significance (2-sided)=.000,Likelihood Ratio: 53.025 values; df=12; Asymp. Significance (2-sided) $=.000$

Linear-by-Linear Association: 3.131 values; df=1; Asymp. Significance (2-sided)=.077 


\subsubsection{Implication for Teaching and Learning}

The fact that students majoring in a given discipline (like architecture) are more likely to have a particular personality characteristic which may be popular to teachers and practitioners. The advantage of a particular characteristic at one stage of architectural design process may be a disadvantage in another stage of design.

For instance, in O.A.U, where the introverted characteristic was highest 55(44\%), it indicates that in such school of architecture, the students require an amount of private time to recharge their batteries. Such students are not offended when shielded from interaction with outside world. In fact the cream of these students are likely to be found in libraries and other secluded places and having their best time to gather momentum for tests, meeting deadlines and enjoy a life of privacy by doing their studio works in the hostels rather than architectural design studio. But it is disadvantageous and possibly a contributing factor to 'deserted studio' menace in most schools.

In another sense, in UNILAG where the introverted characteristics was as low as 20(17.6\%), there is tendency towards extravertedness $52(45.6 \%$ ), where architecture students in this school would feel deprived when design studio activities cut them off from the outside world.

There is something to Phaethon in this case, the cultural environment, the location of the school and accessibility to social connections like the neighborhood facilities.

For O.A.U, the social environment within may be described as good for intra-social activities, but for the external context, the hustling and bustling at O.A.U neighborhoods is low. When compared to UNILAG, there is always an attractive pull from the metropolis, where the students will have to leave the campus for one engagement or the other. This is not so in O.A.U, the pull to interact with the outside world may be described as dull and uninteresting to the students by virtue of location and socio-cultural values.

Therefore, the pedagogy at O.A.U, lle-Ife may need to improvise their curriculum with outing programmes that can edify students' knowledge in terms of knowing places of interests, learning new ideas, and relating to variety of people of different backgrounds, as it pertain to architectural education and experiences. Nutrients can be added to the curriculum by dieting it with extracurricular activities like excursions, workshop practice, site visits, and tour to places of architectural interest and significance. In this case, the town and gown programme may be included in their curriculum and schedules of the school.

\subsubsection{Teachers' Orientation to Life: Extravert (e) versus Introvert (i)}

Respondents' orientation to life in architectural design studio may vary from one individual to another. For respondent teachers, the inclination to design studio is an important point for discussion.

Table 9: Tabulation of Respondents who 'like acting first think \& reflect later'

\begin{tabular}{|l|c|c|c|c|c|c|}
\hline \multirow{2}{*}{ University } & \multicolumn{5}{|c|}{ Teachers who like acting first, think \&reflect later } & \multirow{2}{*}{ Total } \\
\cline { 2 - 6 } & not like me & very little like me & a little like me & like me & a lot like me & \\
\hline CU & $12(66.7)$ & $3(16.7)$ & $0(.0)$ & $2(11.1)$ & $1(5.6)$ & $18(100.0$ \\
LAUTECH & $7(70.0)$ & $2(20.0)$ & $1(10.0)$ & $0(.0)$ & $0(.0)$ & $10(100.0)$ \\
OAU & $4(44.4)$ & $2(22.2)$ & $0(.0)$ & $2(22.2)$ & $1(11.1)$ & $9(100.0)$ \\
UNILAG & $5(41.7)$ & $1(8.3)$ & $3(25.0)$ & $3(25.0)$ & $0(.0)$ & $12(100.0)$ \\
Total & $\mathbf{2 8 ( 5 7 . 1 )}$ & $\mathbf{8 ( 1 6 . 3 )}$ & $\mathbf{4 ( 8 . 2 )}$ & $\mathbf{7 ( 1 4 . 3 )}$ & $\mathbf{2 ( 4 . 1 )}$ & $\mathbf{4 9 ( 1 0 0 . 0 )}$ \\
\hline \multicolumn{2}{|c|}{ Introverted Personality Characteristics= } & Undecided & \multicolumn{2}{c|}{ Extraverted Personality Characteristics. } \\
\multicolumn{2}{|l|}{ 36 Respondents (73.4) } & & \multicolumn{4}{c}{ 9 Respondents (22.5) } \\
\hline
\end{tabular}

Figure in Bracket Presents Percentages, Number outside the Bracket represents Frequencies

Among the reasons for deserted studios, as pointed out some years a go by Rapoport's analytical model Adeyemi, (2000) was basically on the instructional techniques of design studio teachers. This rested on the teachers' orientation to the total life experience in the design studio; some of the reasons correctly outlined were that: (a) Programmes handed out by architectural design studio teachers have been uninteresting, irrelevant, sometimes nonsensical, showing an artificial origin and lack of care and imagination in preparation (b) the student has not known where to start or how to progress (c) he has not known how to judge what he has done (self- criticism) etc.

It is the design studio teacher's primary role to handle the programmes with sensible, interesting, relevant and imaginative techniques and pedagogic principles. The style in which a teacher employs in controlling these factors depicts his orientation and personality characteristics. In this section, the personality characteristics considered in 
respondents (teachers) orientation to design studio in this section are extroverted and introverted characteristics. The essence of the key questions asked was to elicit responses from the respondents as teacher and later find out if there is any relationship between the orientation of the two sets of respondents (staff and students).

\subsection{Respondents as Teachers 'Who Like Acting First before Thinking and Reflection'}

From Table 9, there was less number 9(22.5\%) of respondents as teachers who like acting first, think and reflect later than those who think and reflect before acting 36(73.4\%). It implies that generally across the selected schools, the respondents as staff liked thinking and reflecting first.

This result suggested that in design studio processes of organizing studio setting, handing over of design studio briefs, design instructional guidelines and tenets of instructions to the architectural design studio students; the teachers first think, reflect and acting later. This is in line with fundamental principles of architectural design studio process: order, arrangement, eurhythmy, symmetry, economy and propriety (Stein and Spreckelmeyer, 1999).

Table 10: Frequency Chart for Teachers who 'feel deprived when cut off from Interaction'

\begin{tabular}{|l|c|c|c|c|c|c|}
\hline \multirow{2}{*}{ University } & \multicolumn{2}{|c|}{ Teachers who feel deprived when cut off from Interaction from outside world } & \multirow{2}{*}{ Total } \\
\cline { 2 - 6 } & not like me & very little like me & a little like me & like me & a lot like me & \\
\hline CU & $1(5.6)$ & $2(11.1)$ & $0(.0)$ & $8(44.4)$ & $7(38.9)$ & $18(100.0)$ \\
LAUTECH & $2(20.0)$ & $1(10.0)$ & $1(10.0)$ & $6(60.0)$ & $0(.0)$ & $10(100.0)$ \\
OAU & $1(11.1)$ & $1(11.1)$ & $2(22.2)$ & $3(33.3)$ & $2(22.2)$ & $9(100.0)$ \\
UNILAG & $2(16.7)$ & $2(16.7)$ & $3(25.0)$ & $4(33.3)$ & $1(8.3)$ & $12(100.0)$ \\
Total & $\mathbf{6 ( 1 2 . 2 )}$ & $\mathbf{6 ( 1 2 . 2 )}$ & $\mathbf{6 ( 1 2 . 2 )}$ & $\mathbf{2 1 ( 4 2 . 9 )}$ & $10(20.4)$ & $\mathbf{4 9}(100.0)$ \\
\hline
\end{tabular}

Introverted Personality Characteristics= Undecided Extraverted Personality Characteristics=

12 Respondents (24.4) 31 Respondents (63.3)

Figure in Bracket Presents Percentages, Number outside the Bracket represents Frequencies

When design studio teachers played the role as facilitators of design studio programmes, it will be a denial to organize studios in a manner that the studio instructors would be cut off from the design procedures. Since it is a systematic process, a facilitator is expected to engage all participants (students) in the activities to bring out design potentials in the participants. The design potentials' inhibition can result if the facilitators or the participants are side lined from useful activities.

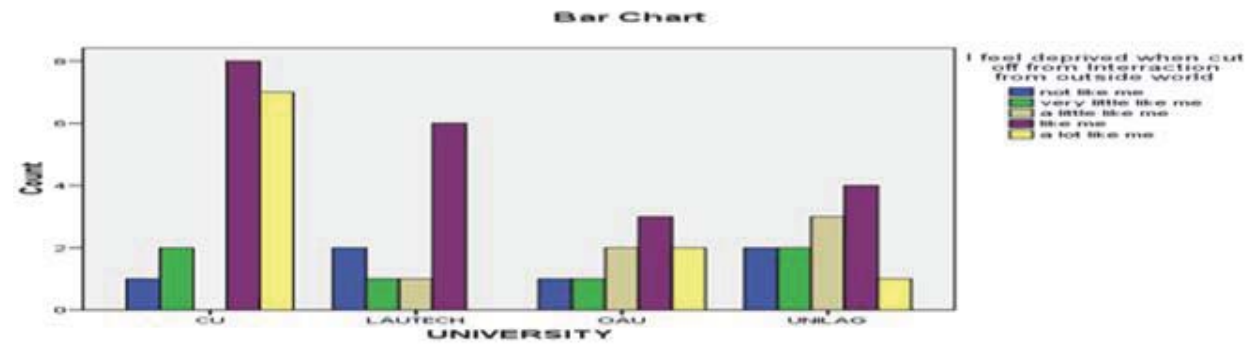

Figure 1: Bar Chart for Teachers who 'feel deprived when cut off from interaction'

In the Table 11, most teachers $28(57.1 \%)$ in the selected schools had extraverted personalities while a few $11(22.5 \%)$ had introverted traits. In this case, it means that most of them are prone to being usually open to and motivated by world of people and things, in essence, their reactions to design studio teachings and instructions would likely be influenced by external world. 
Table 11: Frequency Chart for Staffs who 'are usually open to and motivated by outside World of people and things'

\begin{tabular}{|c|c|c|c|c|c|c|}
\hline \multirow{2}{*}{ University } & \multicolumn{5}{|c|}{ Teachers who are usually Open and Motivated by outside world of people and things } & \multirow[t]{2}{*}{ Total } \\
\hline & not like me & very little like me & a little like me & like me & a lot like me & \\
\hline CU & $1(5.6)$ & $2(11.1)$ & $0(.0)$ & $8(44.4)$ & $7(38.9)$ & $18(100.0)$ \\
\hline LAUTECH & $2(20.0)$ & $0(.0)$ & $4(40.0)$ & $4(40.0)$ & $0(.0)$ & $10(100.0)$ \\
\hline & $0(.0)$ & $2(22.2)$ & $1(11.1)$ & $3(33.3)$ & $3(33.3)$ & $9(100.0)$ \\
\hline UNILAG & $1(8.3)$ & $3(25.0)$ & $5(41.7)$ & $2(16.7)$ & $1(8.3)$ & $12(100.0)$ \\
\hline Total & $4(8.2)$ & $7(14.3)$ & 10(20.4) & $17(34.7)$ & $11(22.4)$ & $49(100.0)$ \\
\hline \multicolumn{3}{|c|}{$\begin{array}{r}\text { Introverted Personality Characteristics= } \\
11 \text { Respondents }(22.5)\end{array}$} & Undecide & \multicolumn{3}{|c|}{$\begin{array}{r}\text { Extraverted Personality Characteristics= } \\
28 \text { Respondents }(57.1)\end{array}$} \\
\hline
\end{tabular}

Such teachers would likely be inclined to participatory revolutionary pedagogic practices (Aderonmu, 2013; Aderonmu, Adeyemi and Amole, 2015); where the teachers engage the students in the users/clients interaction in the community participation of design decision making. While the other teachers may likely teach students to engage in design activities that does not give room for outer world of people and things. Such teachers may likely be engaged in pedagogic practice of hidden curriculum revolutionary model (Aderonmu, 2013); where teachers engaged students in design activities that involve intellectual and social moves. This allows shifting between analytic, synthetic, and evaluative modes of thinking in different sets of activities.

Table 12: Frequency Chart for Staffs who 'enjoy wide variety and change in people relationship'

\begin{tabular}{|l|c|c|c|c|c|c|}
\hline \multirow{2}{*}{ University } & \multicolumn{5}{|c|}{ Teachers who enjoy wide variety and Change in People's Relationship } & \multirow{2}{*}{ Total } \\
\cline { 2 - 6 } & not like me & very little like me & a little like me & like me & a lot like me & \\
\hline CU & $1(5.6)$ & $3(16.7)$ & $3(16.7)$ & $6(33.3)$ & $5(27.8)$ & $18(100.0)$ \\
LAUTECH & $1(10.0)$ & $0(.0)$ & $4(40.0)$ & $5(50.0)$ & $0(.0)$ & $10(100.0)$ \\
OAU & $0(.0)$ & $2(22.2)$ & $2(22.2)$ & $4(44.4)$ & $1(11.1)$ & $9(100.0)$ \\
UNILAG & $1(8.3)$ & $4(33.3)$ & $4(33.3)$ & $2(16.7)$ & $1(8.3)$ & $12(100.0)$ \\
Total & $3(6.1)$ & $9(18.4)$ & $13(26.5)$ & $17(34.7)$ & $7(14.3)$ & $49(100.0)$ \\
\hline \multicolumn{2}{|r|}{ Introverted Personality Characteristics= } \\
\multicolumn{2}{|c|}{ 12 Respondents(24.5) } & \multicolumn{3}{|c|}{ Extraverted Personality Characteristics= } \\
\hline
\end{tabular}

Figure in Bracket Presents Percentages, Number outside the Bracket represents Frequencies

Generally, across the four selected schools $49 \%$ of the Teachers had extraverted personality traits that enjoy wide variety and change in people relationship, while only 24.5 did not enjoyed such variety and change in people relationship.CU had most (22.5\%) Teachers in this category, next to it were OAU (10.2\%) and LAUTECH (10.2\%), while UNILAG (6.1\%) had Teachers with the least type of personality characteristics.

It suggests that in $\mathrm{CU}$ the orientation of teachers towards the design studio involved students in design activities that would enable them to enjoy wide variety of design exposures in meeting different categories of people's relationship.

Table 13: Frequency Chart for Staffs who 'prefer outer World of Activities to One-to-One Communications'

\begin{tabular}{|c|c|c|c|c|c|c|}
\hline \multirow[t]{2}{*}{ University } & \multicolumn{5}{|c|}{ Teachers who prefer outer world of activities, excitements, people \&things to one-to-one communication } & \multirow[t]{2}{*}{ Total } \\
\hline & not like me & very little like me & a little like me & like me & a lot like me & \\
\hline CU & $4(22.2)$ & $5(27.8)$ & $1(5.6)$ & $6(33.3)$ & $2(11.1)$ & 18(100.0) \\
\hline LAUTECH & 2(20.0) & 2(20.0) & $2(20.0)$ & $4(40.0)$ & $0(.0)$ & 10(100.0) \\
\hline OAU & $1(11.1)$ & $3(33.3)$ & $1(11.1)$ & $4(44.4)$ & $0(.0)$ & $9(100.0)$ \\
\hline UNILAG & $0(.0)^{\prime}$ & $3(25.0)$ & 4(33.3) & 4(33.3) & $1(8.3)$ & $12(100.0)$ \\
\hline Total & $7(14.3)$ & $13(26.5)$ & $8(16.3)$ & $18(36.7)$ & $3(6.1)$ & 49(100.0) \\
\hline \multicolumn{3}{|c|}{$\begin{array}{r}\text { Introverted Personality Characteristics= } \\
20 \text { Respondents }(40.8)\end{array}$} & Undecided & \multicolumn{3}{|c|}{$\begin{array}{r}\text { Extraverted Personality Characteristics= } \\
21 \text { Respondents }(42.8)\end{array}$} \\
\hline
\end{tabular}

Figure in Bracket Presents Percentages, Number outside the Bracket represents Frequencies

This is possibly, according to observation, CU runs a modular rotational design activity series that enables design students to experience a wide variety of design types and people's relationship ranging from students, staff, to communities and people. 
From Table 13, generally across the four selected schools, $42.8 \%$ of the Teachers preferred outer world of activities to one-to-one communication. While $40.8 \%$ preferred to teach design studio based on one-to-one communication. Although, the popular mode of teaching design studio used to be by desk crits, where the teachers move from one table to another in order to attend to individual needs of the design students.

This suggests that the existing mode of teaching based on one-to-one communication in the four selected schools has dropped overtime by $42.8 \%$. Therefore, it is expected that teachers need to pay more attention to one-to-one communication because of its inherent pedagogic benefits. Besides having personal contact with each students, other benefits includes, the development of the teacher and students abilities to dialogue design solutions, special abilities are develop to resolve special design problems and students' development of trust and confidence in teachers ability that leads to design solutions.

\subsubsection{Synthesis of 5-Dimensions of Orientation to Life in Architectural Design Studio Pedagogy}

The orientation to life as a pedagogic factor is very important in the process of training architects in order to meet with the societal demands. This aspect of the study identified a nexus where the introverted and extraverted personality characteristics of both respondents are related.

\subsubsection{Pedagogical Predilections and Implications}

From the Table 14, the personality characteristics of students is observed to be at its strongest point(predilections or strong likeness) when the extraverted characteristics of most 252(51.2\%) respondents (students) preferred acting first before thinking and reflecting on architectural design studio matters. Comparatively, it was observed that more teachers declined from acting first; they preferred to think and reflect before acting. This is quite good on the part of the teachers. It is also subjective to a specific stage of design process.

Table 14: Synthesis of 5-Dimensions of Orientation to Life in Architectural Design Studio Pedagogy

\begin{tabular}{|c|c|c|c|c|c|c|c|c|c|c|c|c|}
\hline \multirow{3}{*}{\begin{tabular}{|l|} 
Personality \\
Characteristics
\end{tabular}} & \multicolumn{10}{|c|}{ Introverted -Extraverted Personalities Characteristics of Respondents in Four Selected Schools } & \multirow{2}{*}{\multicolumn{2}{|c|}{$\begin{array}{l}\text { Total Mean Index } \\
\text { For Extraversion- } \\
\text { Extroverson } \\
\text { Personality } \\
\text { Characteristics } \\
\text { (student and teacher) }\end{array}$}} \\
\hline & \multicolumn{2}{|c|}{\begin{tabular}{|l|} 
Resp. who like \\
acting first, think \\
\&reflect later
\end{tabular}} & \multicolumn{2}{|c|}{$\begin{array}{l}\text { Resp. who feel } \\
\text { deprived when } \\
\text { cut off from } \\
\text { Interaction from } \\
\text { outside world }\end{array}$} & \multicolumn{2}{|c|}{$\begin{array}{c}\text { Resp. who are } \\
\text { usually Open } \\
\text { and Motivated } \\
\text { by outside world } \\
\text { of people and } \\
\text { things } \\
\end{array}$} & \multicolumn{2}{|c|}{$\begin{array}{l}\text { Resp. who enjoy } \\
\text { wide variety and } \\
\text { Chang in People's } \\
\text { Relationship }\end{array}$} & \multicolumn{2}{|c|}{$\begin{array}{l}\text { Resp. who prefer outer } \\
\text { world of } \\
\text { activities,excitements,p } \\
\text { eople\&things to one-to- } \\
\text { one communication }\end{array}$} & & \\
\hline & Iv & Ex & Iv & Ex & Iv & Ex & Iv & Ex & Iv & Ex & $\begin{array}{c}\text { IV } \\
\text { (per cent) }\end{array}$ & $\begin{array}{c}\text { Ex } \\
\text { (per cent) }\end{array}$ \\
\hline $\begin{array}{l}\text { Students' } \\
\text { Frequency } \\
\text { (per cent) }\end{array}$ & $\begin{array}{c}105 \\
(21.4 \%)\end{array}$ & $\begin{array}{c}252 \\
(51.2)\end{array}$ & $\begin{array}{c}147 \\
(29.6)\end{array}$ & $\begin{array}{c}216 \\
(43.5)\end{array}$ & $\begin{array}{c}197 \\
(40.1)\end{array}$ & $\begin{array}{c}151 \\
(30.7)\end{array}$ & $\begin{array}{c}198 \\
(41.6)\end{array}$ & $\begin{array}{l}157 \\
(33)\end{array}$ & $\begin{array}{c}190 \\
(38.4)\end{array}$ & $\begin{array}{c}182 \\
(36.8)\end{array}$ & 34.2 & 39 \\
\hline $\begin{array}{l}\text { Teachers' } \\
\text { Frequency } \\
\text { (per cent) }\end{array}$ & $\begin{array}{c}36 \\
(73.4)\end{array}$ & $\begin{array}{c}9 \\
(22.2)\end{array}$ & $\begin{array}{c}12 \\
(24.4)\end{array}$ & $\begin{array}{c}31 \\
(63.3)\end{array}$ & $\begin{array}{c}11 \\
(22.5)\end{array}$ & $\begin{array}{c}28 \\
(57.1)\end{array}$ & $\begin{array}{c}12 \\
(24.5)\end{array}$ & $\begin{array}{c}24 \\
(49.0)\end{array}$ & $\begin{array}{c}20 \\
(40.8)\end{array}$ & $\begin{array}{c}21 \\
(42.8)\end{array}$ & 37.1 & 46.9 \\
\hline
\end{tabular}

Figure in Bracket Presents Percentages, Number outside the Bracket represents Frequencies; Iv. Means 'Introverted', Ex.means 'Extraverted'\& Resp.means Respondents

Efforts should be made to control this at the stance of sudden illumination of ideas; as ideas are seeds that grow to form and functions of design. For a successful design endeavour, allowance should be given to thinking and reflection before formalizing such ideas into a design concept. The art and science of critical thinking should be properly engaged in this scenario. The architectural design studio teachers in this type scheme needs to develop an effective instructional tools and strategies to control such design studio clique.

This can be achieved before or during initiation stage of design studio process by organizing the students into portable groups where brainstorming and discussion can be made; contributions of participants would be asked to be documented and submitted to the studio instructor or teacher. The same illuminated ideas can then be followed up by giving each group an esquisse (quick approach or short term projects) that would be expected to proffer different solutions.

Bearing in mind the first objective in this study, it was to examine the personality characteristics of Students and Staff in relation to architectural design studio. The characteristic examined in this first section was the orientation of staff 
and students to life as they approached their studio undertakings or assignments.

Table 15: Five (5) Dimension Pedagogic Polarity of Introverted -Extraverted Characteristics in Four (4) Selected Schools

\begin{tabular}{|c|c|c|c|c|c|c|c|c|c|c|c|c|}
\hline & \multirow{2}{*}{\multicolumn{2}{|c|}{$\begin{array}{l}\text { Respondents } \\
\text { who like } \\
\text { acting first, } \\
\text { think \&reflect } \\
\text { later }\end{array}$}} & \multirow{2}{*}{\multicolumn{2}{|c|}{$\begin{array}{c}\text { Respondents } \\
\text { who feel deprived } \\
\text { when cut off from } \\
\text { Interaction from } \\
\text { outside world }\end{array}$}} & \multicolumn{2}{|c|}{\begin{tabular}{|} 
Respondents \\
who are \\
usually Open \\
and Motivated \\
by outside \\
world of people \\
and things
\end{tabular}} & \multicolumn{2}{|c|}{$\begin{array}{l}\text { Respondents } \\
\text { who enjoy } \\
\text { wide variety } \\
\text { and Change } \\
\text { in People's } \\
\text { Relationship }\end{array}$} & \multicolumn{2}{|c|}{$\begin{array}{l}\text { Respondents } \\
\text { who prefer } \\
\text { outer world of } \\
\text { activities } \\
\text {,excitements, } \\
\text { people \&things } \\
\text { to one-to-one } \\
\text { communication }\end{array}$} & \multicolumn{2}{|c|}{$\begin{array}{l}\text { 5-dimension } \\
\text { introverted- } \\
\text { extroverted } \\
\text { characteristics } \\
\text { Mean Index }\end{array}$} \\
\hline & & & & & & $-E 3$ & & & & & Average & otal(\%) \\
\hline & IV & Ex & IV & Ex & IV & Ex & IV & Ex & IV & Ex & IV & Ex \\
\hline Respondents Student (\%) & 21.4 & 51.2 & 29.6 & 43.5 & 40.1 & 30.7 & 41.6 & 33 & 38.4 & 36.8 & 34.2 & 39 \\
\hline Respondents Staff (\%) & 73.4 & 22.2 & 24.4 & 63.3 & 22.5 & 57.1 & 24.5 & 49.0 & 40.8 & 42.8 & 37.1 & 46.9 \\
\hline
\end{tabular}

- Iv. Means'Introverted', Ex.means'Extraverted' (all in per cents- \%)

\subsubsection{Establishing the Correlation Factors between the Personality Characteristics of Respondents as Students and Staffs}

This was done by analyzing their responses and the results were shown above. I-E1-5 indicates the 5-dimension pedagogic polarity of introverted-extroverted characteristics schemata from table 15 , the average values of introverted personality traits were comparatively higher (37.1\%) in respondents as staff than respondents (34.2\%) as students. In the same like manner, in the figure 2 below, the extraverted characteristics were also higher in respondents as staff (46.9\%) than respondents as students.

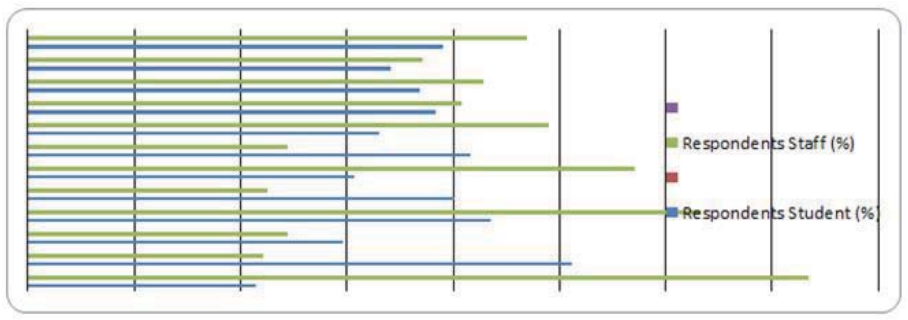

Figure 2: Showing Correlation Factors between the Personalities Characteristics of Respondents as Students and Staffs

From the Table 14 and figure 2, from series I-E1 to I-E5 of the personality series of the respondents, the highest personality factor $(73.4 \%)$ was observed in I-E1 of most respondents(73.4\%) staff with intuitive traits; and highest extraverted personality traits was also in I-E1 but for all respondents as students in the four selected schools. It indicates that in I-E1 as a predictor of introverted and extroverted characteristics of other factors (I-E2, I-E3, I-E4, and I-E5).

\subsubsection{The Pedagogic Predilections of I-E1 on Architectural Design Studio, Action, Thinking, Reflection and Performance}

During design process and its evolution, the temptation and propensity to act first before thinking is always imminent. But in the real world situation where feasibility, precision, accurate measurement, analysis and specification are required for a constructible design; there is need for designers to navigate control over their minds strata and design issues. In I-E1, the respondents as students had more extraverted characteristics than the other respondents as staff; with most introverted traits in respondents (teachers/staff) than the respondents as students. In a simpler manner, most respondents (73.4\%) as staff (teachers) like to think and reflect on architectural design issues while few (21.4\%) respondents as students had orientation in the same way.

Therefore, since thinking and reflection are both tools in the hand and mind of any successful designer, the stakeholders (especially the teachers) need to navigate a shift and strike a balance between these characteristics in 
handling studio instructions to students. Generally, the orientation to life in design studio in the four (4) selected schools needs to balance the wide discrepancies between the introverted personality traits of both respondents. Because reflection, thinking and action employed may thus be said to depend on the nature of design process and situation. Good thinking is required from inception to completion of almost every projects, therefore balance must be employed between thinking and acting so as to prevent delay in both cases.

The architectural design thinkers' orientation to the external world, control over his thought processes and inner personal needs (Uji, 2002) are important influences and determines the predominance of certain thinking styles observable in certain individuals' vis-à-vis the design outcomes emerged from such designers.

\section{Conclusion}

This paper submits that 'there is a difference in the design approach of students who preferred acting first before thinking and reflection and; the one who prefer thinking and reflection before acting across the selected schools of architecture. In respect of design outcomes of students who are usually open and motivated by outside world in the selected schools, the study concludes that a difference exists between the design outcomes of the extraverted and introverted architectural designers. Therefore, the synergy of polar characteristic differences of the students need to be creatively engaged by the design studio teachers during training in school to prepare the students for professional competency in practice. Finally, these differences while in training also extend to characteristic dispositions and nature of design proffered by architectdesigners as solutions to clients, communities and cities of the world today.

\section{Suggestions for Further Studies}

Examining other MBTI faces i.e intuition and sensing, feeling and judgment is suggested for future study.

Also, interactions between the extroversion-introversion personalities should be investigated in a group work dynamics at school and in practice; this would help to harvest a good outcome in interpersonal collaborative engagements. Therefore, stakeholders need to do more in school; the mentors need to be involved in serious observation of these characteristics and engage them creatively i.e constant engagements between students and teachers with project activities in order to establish synergy and mutual design benefits between people with polar characteristics.

Finally, these characteristics should be tested within a non-academic environment to determine if the personality characteristics of design students, teachers and teams of professionals in the building industry can be better engaged during mentoring and professional practice in construction projects and works.

\section{References}

Aderonmu, P.A (2013). Aderonmu, P. A. (2013). The Design Studio in Selected Schools of Architecture in South-West Nigeria: a Study of Pedagogy, Culture and Environment. (Unpublished Ph.D thesis). Covenant University, Nigeria.

Aderonmu, P.A, Adeyemi E.A, and Amole S.A (2015). The Charrette's Role in Sustainable National Development: Participatory Education, Community Development and Governance Practices in Nigeria. 2015 Architects Colloquium, Musa Yara' adua Center, Abuja. 8-10 June, 2015

Adeyemi, E. A. (2000). Lest We Forget. AARCHES Journal, 1(3): 1-3

Briggs, M. I. (1980) Gifts Differing: Understanding Personality Type. Available on http://www.humanmetrics.com/personality/type. Accessed on January 4, 2016

Casakin, H. (2005). 'Metaphors as an unconventional reflective approach in architectural design', The Design Journal, 9(1): 37 - 50.

Casakin, H., (2006). Assessing the use of metaphors in the design process, Environment and Planning B: Planning and Design, 33(2): 253-268.

Casakin, H. and Miller, K. (2008). 'Individual learning styles and design performance in the metaphorical reasoning process', J. Design Research, $\mathrm{x}(\mathrm{x}): \mathrm{xx}-\mathrm{xx}$.

Covenant University, (2013). Department of Architecture Hand Book. Corporate Affairs, Covenant University, Ota

Demirbas, O. O., (2001). The Relation of Learning Styles and Performance Scores of Students in Interior Architecture Education (Doctoral Thesis, Bilkent University, Turkey, 2001)

Demirbas, O. O. and Demirkan, H., (2003). Focus on architectural design process through learning styles. Design Studies, 24: 437-456

Durling, D. (1994). Hyping style: approaches to design. Interact, (1)4: 19-21

George, T. O., Anyaegbunam, M. C., Azuh, D., Chine, B. C and Omonijo, D. O. (2015). Influence of Personality Types and SocioDemographic Characteristics of Student Work-Study Programme at a Private University, Southwest Nigeria. Mediterranean Journal of Social Science, 6(6z4):453-464

Groulx, T. J. (2010). An examination of the influence of band director teaching style and personality on ratings at concert and marching 
band events. A dissertation submitted in partial fulfillment of the requirements for the degree of Doctor of Philosophy Center for Music Education Research School of Music College of the Arts, University of South Florida.

Jung, C. G. (1971). Psychological types (Collected works of C. G. Jung, volume 6, Chapter X)

Kolb, D. A. (1984). "Experiential learning: Experience as the Source of Learning and Development". Englewood Cliffs, NJ: Prentice-Hall

Kvan, T. and Yunyan, J., (2005). Student's learning styles and their correlation with performance in architectural design studio. Design Studies, 26(1): 19-34.

Ladoke Akintola University of Technology, (2013). Department of Architecture Handbook, 2012/2013 Session. Ogbomoso.

Lawrence, G. (1984) A synthesis of learning style research involving the MBTI. Journal of Psychological Type, (8): 2- 15.

McGuire, W., \& Hull, R. F. C. (Eds.). (1977). "C. G . Jung speaking”. Princeton, NJ: Princeton University Press.

Obafemi Awolowo University, (2012). Architecture Department Handbook. Ile Ife: Obafemi Awolowo University Press

Rotimi, O. A., Omonijo, D. O and Uche, O. O. U. (2014). Influence of Personality Types and Socio-Demographic Characteristics of Students on Examination Malpractice in Ibadan. European Journal of Scientific Research, 124(4): 486-499

Schmeck, R. (1985). Learning styles of college students. In: Dillon, R. \& Schmeck, R. (Eds.) Individual differences in cognition: Vol. 1. Academic Press, New York.

Stein, J. M and Spreckelmeyer, K. F. (1999). "Classical Readings in Architecture: The Education of the Architect". McGraw-Hill Companies: New York

TNEB, (2007). "Universalium Personality. The New Encyclopedia Britannica, 15th Edition". Chicago Publisher. Available on unversalium.academic.ru/170368 personality.

Uji, Z. A. (2002). "Evolution of Design thought; the Intuitive, Imaginative and Creative Approach". Yola: Paraclete Publishers University of Lagos (2012). Architecture Departmental Handbook, 2011/2012. Lagos. University of Lagos Press. 